\title{
National Survey of Influenza Myocarditis in Japanese Children in Three Seasons
}

\author{
Akira Ukimura ${ }^{1,2^{*}}$, Kanta Kishi ${ }^{3}$, Tomoyuki Yamada ${ }^{2}$, Yuriko Shibata ${ }^{2}$, Yukimasa Ooi ${ }^{1,2}$, Yumiko Kanzaki ${ }^{1}$ and Hiroshi Tamai ${ }^{3}$ \\ ${ }^{1}$ Department of General Internal Medicine, Osaka Medical College, Takatsuki, Japan \\ 2Infection Control Team, Osaka Medical College Hospital, Takatsuki, Japan \\ ${ }^{3}$ Department of Pediatrics, Osaka Medical College, Takatsuki, Japan
}

\begin{abstract}
An Influenza pandemic occurred in 2009. A nationwide, retrospective survey of Influenza myocarditis in Japanese children in 3 consecutive Influenza seasons was performed to compare Influenza myocarditis in the 2009/2010 season (the pandemic season), the 2010/2011 season, and the 2011/2012 season, by mailing questionnaires to 514 hospitals in Japan that have pediatric departments and collecting data from 285 hospitals. A questionnaire-based survey related to Influenza myocarditis was also conducted to evaluate the attitudes of Japanese pediatricians concerning the diagnosis of Influenza myocarditis. Fifteen Influenza myocarditis patients were reported, with 8 (H1N1pdm:6, type A:1, type B:1) from the 2009/10 season, 4 (type A:1, type B:3) from the 2010/11 season, and 3 (type B:3) from the 2011/12 season. Only 8 patients with Influenza A virus myocarditis were reported, with 7 patients from the 2009/2010 season, one from the $2010 / 2011$ season, and none in the 2011/2012 season. Mortality was $33.3 \%$ $(5 / 15)$ among the myocarditis patients. Twelve patients $(12 / 15,80 \%)$ were diagnosed with fulminant myocarditis with fatal arrhythmias and/or cardiogenic shock. In the pediatricians' attitude survey, only $3.3 \%$ of pediatricians routinely examined the electrocardiograms of children hospitalized with Influenza infection in Japan. The number of Japanese children with myocarditis associated with Influenza A virus seemed to increase in the pandemic season. Increased awareness of Influenza myocarditis in children is needed during future Influenza pandemics.
\end{abstract}

Keywords: Myocarditis; Influenza; Pandemic; Cardiogenic shock

\section{Introduction}

Acute myocarditis is a potentially lethal disease, and the etiological agents of viral myocarditis include Enteroviruses, Adenoviruses, Parvoviruses, Cytomegalovirus, Influenza virus and others [1-10]. Fulminant myocarditis causes severe hemodynamic dysfunction and requires high-dose catecholamine and mechanical circulatory support [1,6-8,11]. An Influenza pandemic occurred in 2009 [6,1214]. The causative organism, Influenza H1N1pdm, has been reported to cause fatal myocarditis as well as pneumonia [2-4,6-10]. Based on national surveillance in Japan, we previously reported that fifteen fulminant myocarditis patients (adults: 13, children: 2) with Influenza A H1N1pdm were seen in the 2009/2010 season, while only two (adults: 2, children: 0) were seen in the 2010/2011 season, and that electrocardiogram (ECG) was useful for screening for myocarditis [7].

\section{Patients and Methods}

A nationwide, retrospective survey of Influenza myocarditis in Japanese children in 3 consecutive Influenza seasons was performed to compare Influenza myocarditis in the 2009/2010 season (the pandemic season), the $2010 / 2011$ season, and the $2011 / 2012$ season by mailing questionnaires to 514 hospitals in Japan that have pediatric departments. A fill-in-the-blanks and multiple-choice questionnaire was designed to obtain information on patient profiles, laboratory findings, treatment, outcomes and other data. Myocarditis was diagnosed using the Guidelines for Diagnosis and Treatment of Myocarditis (JCS 2009). The presence of compatible clinical symptoms, echocardiographic abnormalities in the absence of cardiac ischemia, leakage of cardiac enzymes and/or other evidence of myocardial damage suggested that a diagnosis of myocarditis was highly probable. Laboratory diagnosis of Influenza was made by quick Influenza diagnostic testing or probe-based real-time polymerase chain reaction (RT-PCR) using a nasopharyngeal swab or sputum, or viral titer elevation. A questionnaire-based survey related to Influenza myocarditis was performed to evaluate the attitudes of Japanese pediatricians concerning the diagnosis of Influenza myocarditis. The study protocol was approved by the Institutional Review Board of Osaka Medical College.

\section{Results}

Completed questionnaires were received from 285 hospitals that have pediatric departments in Japan. About 300,000 children were admitted per year in these hospitals. Fifteen Influenza myocarditis patients were reported, with 8 (H1N1pdm2009:6, type A:1, type B:1) from the 2009/2010 season, 4 (type A:1, type B:3) from the 2010/2011 season, and 3 (type B:3) from the 2011/2012 season (Table 1). Only 8 patients with Influenza A virus myocarditis were reported, with 7 patients from the 2009/2010 season, only one from the 2010/2011 season, and none in the 2011/2012 season (H3N2 dominant season). Cardiac symptoms developed on the first to third day of illness in most patients. Mortality was $33.3 \%$ (5/15) among the myocarditis patients. Twelve patients $(12 / 15,80 \%)$ were diagnosed with fulminant myocarditis with fatal arrhythmias and/or cardiogenic shock. Myocardial circulatory support was emergently inserted in 4 patients, three of whom were rescued. Three of the 9 patients treated without myocardial circulatory support survived. Respirators were used in 9 patients. Myocardial biopsies were not performed, and autopsy showed myocarditis in two patients.

*Corresponding author: Akira Ukimura, Department of General Internal Medicine, Osaka Medical College, 2-7 Daigaku-machi, Takatsuki 569-8686, Japan, Tel: +8172-683-1221; Fax: +81-72-684-7386; E-mail: in3011@poh.osaka-med.ac.jp

Received February 21, 2014; Accepted April 15, 2014; Published April 20, 2014

Citation: Ukimura A, Kishi K, Yamada T, Shibata Y, Ooi Y, et al. (2014) National Survey of Influenza Myocarditis in Japanese Children in Three Seasons. Clin Microbial 3: 143. doi:10.4172/2327-5073.1000143

Copyright: (C) 2014 Ukimura A, et al. This is an open-access article distributed under the terms of the Creative Commons Attribution License, which permits unrestricted use, distribution, and reproduction in any medium, provided the original author and source are credited. 
Citation: Ukimura A, Kishi K, Yamada T, Shibata Y, Ooi Y, et al. (2014) National Survey of Influenza Myocarditis in Japanese Children in Three Seasons. Clin Microbial 3: 143. doi:10.4172/2327-5073.1000143

Page 2 of 3

\begin{tabular}{|c|c|c|c|c|c|c|c|c|c|c|c|c|c|c|}
\hline \multicolumn{15}{|c|}{ Characteristics of paediatric myocarditis patients associated with influenza virus in $\mathbf{3}$ seasons in Japan } \\
\hline $\begin{array}{c}\text { Season/ } \\
\text { Patient } \\
\text { No. }\end{array}$ & $\begin{array}{l}\text { Age/ } \\
\text { sex }\end{array}$ & $\begin{array}{l}\text { Baseline } \\
\text { Disease }\end{array}$ & \begin{tabular}{|c|} 
Card \\
iac symptom/ \\
onset (day post \\
symptoms of \\
influenza)
\end{tabular} & $\begin{array}{c}\text { Type of } \\
\text { myocarditis }\end{array}$ & $\begin{array}{l}\text { Pneumonia or } \\
\text { Enchepalopathy }\end{array}$ & $\begin{array}{l}\text { RT-PCR } \\
\text { or rapid } \\
\text { diagnostic } \\
\text { testing }\end{array}$ & ECG findings & $\begin{array}{l}\text { Echocardiographic } \\
\text { findings }\end{array}$ & $\begin{array}{l}\text { Peak of } \\
\text { Cardiac } \\
\text { Enzyme }\end{array}$ & $\begin{array}{l}\text { Medical } \\
\text { treatment }\end{array}$ & Ventilator & $\begin{array}{c}\text { Mechanical } \\
\text { Support }\end{array}$ & $\begin{array}{l}\text { Biopsy or } \\
\text { Autopsy }\end{array}$ & Outcome \\
\hline $\begin{array}{c}2009- \\
2010 / 1\end{array}$ & $5 / \mathrm{M}$ & none & no information & $\begin{array}{c}\text { fulminant } \\
\text { myocarditis }\end{array}$ & no information & $\begin{array}{l}\text { 2009A } \\
\text { (H1N1) }\end{array}$ & $\begin{array}{c}\text { no } \\
\text { information }\end{array}$ & no information & $\begin{array}{c}\text { no } \\
\text { information }\end{array}$ & oseltamivir & used & not used & not done & Death \\
\hline $\begin{array}{l}2009- \\
2010 / 2\end{array}$ & 6/M & asthma & dyspnea/day 3 & $\begin{array}{c}\text { fulminant } \\
\text { myocarditis }\end{array}$ & pneumonia & $\begin{array}{l}\text { 2009A } \\
\text { (H1N1) }\end{array}$ & $\begin{array}{c}\mathrm{VF}, \mathrm{T} \\
\text { inversion }\end{array}$ & $\begin{array}{c}\text { diffuse hypokinesis } \\
\text { EF33\% }\end{array}$ & $\begin{array}{c}\text { CPK } \\
25,224\end{array}$ & oseltamivir & used & $\underline{\text { PCPS }}$ & not done & Improved \\
\hline $\begin{array}{l}2009- \\
2010 / 3\end{array}$ & $11 / \mathrm{F}$ & none & shock/day 3 & $\begin{array}{c}\text { fulminant } \\
\text { myocarditis }\end{array}$ & none & $\begin{array}{l}2009 \mathrm{~A} \\
(\mathrm{H} 1 \mathrm{~N} 1)\end{array}$ & $\begin{array}{l}\text { low voltage } \\
\text { ST elevation }\end{array}$ & $\begin{array}{c}\text { diffuse } \\
\text { hypokinesisedema of } \\
\text { LV wall }\end{array}$ & CK-MB918 & $\begin{array}{l}\text { oseltamivir } \\
\text { steroid } \\
\text { g-globulin }\end{array}$ & used & PCPS IABP & not done & Improved \\
\hline $\begin{array}{l}2009- \\
2010 / 4\end{array}$ & $12 / \mathrm{M}$ & $\begin{array}{l}\text { brain } \\
\text { tumor }\end{array}$ & $\begin{array}{c}\text { consciousness } \\
\text { disturbance/ } \\
\text { day } 1\end{array}$ & $\begin{array}{l}\text { fulminant } \\
\text { myocarditi }\end{array}$ & pneumonia & $\begin{array}{l}\text { 2009A } \\
\text { (H1N1) }\end{array}$ & $\begin{array}{c}\text { low voltage } T \\
\text { inversion }\end{array}$ & diffuse hypokinesis & $\begin{array}{c}\text { no } \\
\text { information }\end{array}$ & $\begin{array}{l}\text { steroid } \\
\text { g-globulin }\end{array}$ & used & not used & not done & Death \\
\hline $\begin{array}{c}2009- \\
2010 / 5\end{array}$ & $15 / \mathrm{M}$ & none & chest pain/day 2 & $\begin{array}{c}\text { acute } \\
\text { myocarditis, }\end{array}$ & none & $\begin{array}{c}\text { elevation } \\
\text { of HI titer } \\
\text { (Influenza A) }\end{array}$ & ST elevation & pericardial effusion & $\begin{array}{l}\text { CPK } 304 \\
\text { CK-MB } 56\end{array}$ & $\begin{array}{l}\text { conservative } \\
\text { therapy }\end{array}$ & not used & not used & not done & Improved \\
\hline $\begin{array}{l}2009- \\
2010 / 6\end{array}$ & 7/M & none & chest pain/day 2 & $\begin{array}{c}\text { fulminant } \\
\text { myocarditis }\end{array}$ & none & $\begin{array}{l}\text { 2009A } \\
\text { (H1N1) }\end{array}$ & $\begin{array}{l}\text { sinus } \\
\text { tachycardia } \\
\text { low voltage }\end{array}$ & $\begin{array}{l}\text { hypokinesis with } \\
\text { pericardial effusion }\end{array}$ & $\begin{array}{c}\text { CPK } 5,163 \\
\text { CK-MB } \\
128\end{array}$ & $\begin{array}{l}\text { oseltamivir, } \\
\text { g-globulin }\end{array}$ & used & not used & not done & Improved \\
\hline $\begin{array}{l}2009- \\
2010 / 7\end{array}$ & $14 / \mathrm{F}$ & none & dyspnea/day 3 & $\begin{array}{c}\text { fulminant } \\
\text { myocarditis }\end{array}$ & none & $\begin{array}{l}\text { 2009A } \\
\text { (H1N1) }\end{array}$ & T inversion & pericardial effusion & $\begin{array}{c}\text { no } \\
\text { information }\end{array}$ & $\begin{array}{c}\text { conservative } \\
\text { therapy }\end{array}$ & not used & not used & $\frac{\text { Autopsy mild }}{\text { myocarditis }}$ & Death \\
\hline $\begin{array}{c}2009- \\
2010 / 8\end{array}$ & $8 / F$ & epilepsy & $\begin{array}{l}\text { dyspnea, chest } \\
\text { pain/ day } 4\end{array}$ & $\begin{array}{c}\text { acute } \\
\text { myocarditis }\end{array}$ & none & $\begin{array}{c}\text { B positive by } \\
\text { rapid test }\end{array}$ & $\mathrm{T}$ inversion & $\begin{array}{l}\text { hypokinesis with } \\
\text { pericardial effusion }\end{array}$ & $\begin{array}{l}\text { CPK } 1933 \\
\text { CK-MB } 33\end{array}$ & g-globulin & not used & not used & not done & Improved \\
\hline $\begin{array}{l}2010- \\
2011 / 1\end{array}$ & $1 / \mathrm{F}$ & none & shock/ day 6 & $\begin{array}{c}\text { fulminant } \\
\text { myocarditis }\end{array}$ & none & $\begin{array}{c}\text { A positive by } \\
\text { rapid test }\end{array}$ & ST elevation & $\begin{array}{c}\text { diffuse hypokinesis } \\
\text { EF20\% }\end{array}$ & $\begin{array}{c}\text { CPK } \\
21,818\end{array}$ & $\begin{array}{l}\text { oseltamivir, } \\
\text { g-globulin }\end{array}$ & used & not used & not done & $\begin{array}{l}\text { Incomplete } \\
\text { improvement }\end{array}$ \\
\hline $\begin{array}{l}2010- \\
2011 / 2\end{array}$ & 7/F & none & $\begin{array}{c}\text { consciounsness } \\
\text { disturbance / } \\
\text { day } 8\end{array}$ & $\begin{array}{l}\text { fulminant } \\
\text { myocarditis }\end{array}$ & none & $\begin{array}{c}\text { B positive by } \\
\text { rapid test }\end{array}$ & $\begin{array}{l}\text { low voltage } \\
\text { ST elevation }\end{array}$ & $\begin{array}{l}\text { diffuse hypokinesis } \\
\text { pericardial effusion }\end{array}$ & $\begin{array}{c}\text { CPK } 7,091 \\
\text { CK-MB } \\
175\end{array}$ & $\begin{array}{l}\text { oseltamivir, } \\
\text { g-globulin } \\
\text { steroid }\end{array}$ & used & not used & not done & Improved \\
\hline $\begin{array}{l}2010- \\
2011 / 3\end{array}$ & $5 / F$ & asthma & $\begin{array}{c}\text { abdominal pain/ } \\
\text { day } 3\end{array}$ & $\begin{array}{c}\text { fulminant } \\
\text { myocarditis }\end{array}$ & none & $\begin{array}{c}\text { B positive by } \\
\text { rapid test }\end{array}$ & $\begin{array}{c}\text { no } \\
\text { information }\end{array}$ & no information & $\begin{array}{c}\text { CPK } \\
\text { elevation }\end{array}$ & zanamivir & not used & not used & $\begin{array}{c}\text { Autopsy } \\
\text { myocarditis }\end{array}$ & Death \\
\hline $\begin{array}{l}2010- \\
2011 / 4\end{array}$ & $11 / \mathrm{F}$ & none & dyspnea/ day 5 & $\begin{array}{l}\text { fulminant } \\
\text { myocarditis }\end{array}$ & none & $\begin{array}{c}\text { B positive by } \\
\text { rapid test }\end{array}$ & ST elevation & diffuse hypokinesis & $\begin{array}{c}\text { CPK } \\
37,979 \\
\text { CK-MB } \\
583\end{array}$ & $\begin{array}{l}\text { peramivir } \\
\text { g-globulin }\end{array}$ & used & $\underline{\text { PCPS }}$ & not done & Improved \\
\hline $\begin{array}{c}2011- \\
2012 / 1\end{array}$ & $8 / F$ & none & dyspnea/ day 3 & $\begin{array}{c}\text { fulminant } \\
\text { myocarditis }\end{array}$ & $\begin{array}{l}\text { enchepalopathy } \\
\text { pneumonia }\end{array}$ & $\begin{array}{c}\text { B positive by } \\
\text { rapid test }\end{array}$ & $\begin{array}{l}\text { low voltage } \\
\text { ST elevation }\end{array}$ & diffuse hypokinesis & $\begin{array}{c}\text { CPK } \\
\text { elevation }\end{array}$ & $\begin{array}{l}\text { peramivir } \\
\text { steroid } \\
\text { g-globulin }\end{array}$ & not used & not used & not done & Improved \\
\hline $\begin{array}{l}2011- \\
2012 / 2\end{array}$ & 6/M & $\begin{array}{c}\mathrm{T} / \mathrm{F} \mathrm{s} / \mathrm{p} \\
\mathrm{OP}\end{array}$ & shock/day 3 & $\begin{array}{c}\text { fulminant } \\
\text { myocarditis }\end{array}$ & encepalopathy & $\begin{array}{c}\text { B positive by } \\
\text { rapid test }\end{array}$ & $\mathrm{T}$ inversion & diffuse hypokinesis & CPK 736 & oseltamivir & used & $\underline{\text { PCPS }}$ & not done & Death \\
\hline $\begin{array}{l}2011- \\
2012 / 3\end{array}$ & $10 / F$ & none & dyspnea day 2 & $\begin{array}{c}\text { acute } \\
\text { myocarditis }\end{array}$ & none & $\begin{array}{c}\text { B positive by } \\
\text { rapid test }\end{array}$ & ST elevation & $\begin{array}{l}\text { pericardial effusion } \\
\text { edema of } L V \text { wall }\end{array}$ & $\begin{array}{c}\text { CPK } \\
13,529 \text { CK- } \\
\text { MB } 277\end{array}$ & $\begin{array}{l}\text { peramivir } \\
\text { steroid } \\
\text { g-globulin }\end{array}$ & not used & not used & not done & Improved \\
\hline
\end{tabular}

Table 1: Characteristics of pediatric myocarditis patients with influenza virus in 3 consecutive seasons in Japan

T/F s/p OP: following surgery for tetralogy of Fallot, RT-PCR: real-time polymerase chain reaction, HI: hemagglutination inhibition, VF: ventricular fibrillation, CPK: creatine phosphokinase, CK-MB: creatine kinase-MB, IABP: intra-aortic balloon pumping, PCPS: percutaneous cardiopulmonary support.

Attitude of Japanese pediatricians in diagnosis of influenza myocarditis

$$
\begin{aligned}
& \text { Q.1 When do you assume influenza } \\
& \text { myocarditis in your pediatric } \\
& \text { influenza patient? }
\end{aligned}
$$

\section{Q.2 Do you exam routinely when their pediatric influenza patient is admitted} to your hospital?
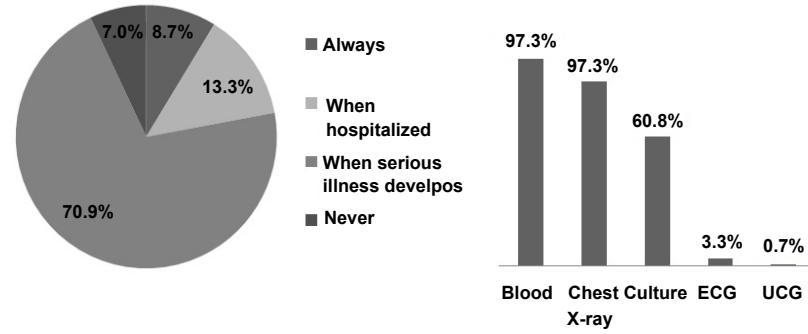

Figure 1: Attitudes of Japanese pediatricians to the diagnosis of influenza myocarditis

Question 1

When do you assume that your pediatric influenza patient may have influenza myocarditis?

Question 2

Which of the following do you examine routinely when your pediatric influenza patient is admitted to hospital?

ECG: Electrocardiogram, UCG: Ultrasound cardiogram

Ten patients had no baseline disease, and only two patients suffered from bronchial asthma. Three patients with myocarditis also developed pneumonia. RT-PCR or quick diagnostic testing yielded positive results in all patients. Most patients showed ECG abnormalities, such as ST segment elevation and/or T wave abnormality (ST-T abnormalities). Echocardiography revealed abnormalities of left ventricular wall motion in 10 patients. Cardiac dysfunction recovered almost completely in 9 patients, but partially remained in one patient. Eleven patients (73\%) were treated with neuraminidase inhibitors.

Answers to the attitude survey concerning the diagnosis of Influenza myocarditis were received from 451 pediatricians (Figure 1). Overall, $8.4 \%$ of Japanese pediatricians always assumed the presence of Influenza myocarditis in pediatric Influenza patients, $13.2 \%$ in hospitalized patients, and $71.3 \%$ in patients with serious illness; however, $7.1 \%$ of Japanese pediatricians never assumed that Influenza myocarditis was present in pediatric Influenza patients. In addition, $87.6 \%$ of Japanese pediatricians routinely examined the chest X-rays when their pediatric patients were admitted to hospital, and $3.3 \%$ of pediatricians routinely examined the ECG, which is useful for screening of myocarditis (Figure 1).

\section{Discussion}

The Ministry of Health, Labor and Welfare of Japan confirmed only 198 deaths among about 20.61 million patients infected with Influenza A H1N1pdm in the 2009/2010 season, and 150 deaths among about 10.3 million patients in the 2010/2011 season in Japan [14]. The low casefatality rate in Japan may be a result of early diagnosis and aggressive early intervention with antiviral drugs $[15,16]$. Twenty-five Influenza H1N1pdm myocarditis patients were reported in the 2009/2010 season, although only 4 were documented in the 2010/2011 season, and only 4 
Citation: Ukimura A, Kishi K, Yamada T, Shibata Y, Ooi Y, et al. (2014) National Survey of Influenza Myocarditis in Japanese Children in Three Seasons. Clin Microbial 3: 143. doi:10.4172/2327-5073.1000143

Page 3 of 3

pediatric myocarditis patients were reported in 2 seasons in our previous study [7]. Since the number of pediatric myocarditis patients seemed to be smaller than in adult patients, this study was performed. Only 8 myocarditis patients with Influenza A virus were reported, with 7 from the $2009 / 2010$ season, only one from the $2010 / 2011$ season, and none in the 2011/2012 season in this study. The number of Japanese children with myocarditis associated with Influenza A virus seemed to increase in the pandemic season. A high prevalence of fulminant myocarditis was observed among the pediatric patients with myocarditis $(12 / 15$, $80 \%)$. Since cardiac symptoms developed on the first to third day of sickness in most pediatric myocarditis patients, and cardiac dysfunction progressed rapidly, early diagnosis and prompt treatment of acute myocarditis with heart failure are required in patients with Influenza infection during the pandemic season [6-10]. Appropriate intervention in patients with fulminant Influenza myocarditis consists of treatment with neuraminidase inhibitors to eliminate the causative virus, and mechanical circulatory support with intra-aortic balloon pumping or percutaneous cardiopulmonary support is very helpful for treating the depressed myocardial function $[1,6-11,15,16]$.

Myocarditis was proven by autopsy in only 2 fulminant myocarditis patients in this study, and the pathological findings were relatively mild. Many kinds of viruses have been implicated as a cause of myocarditis, with different viruses having different potentials to cause myocarditis [1-8]. The affinity of the Influenza virus for cardiac myocytes seemed to be low in previous studies $[1-3,17,18]$. The pathological mechanism of Influenza myocarditis appears to differ depending on the pathogen, and it may depend on host immunity. These results suggest that vaccination is able to suppress myocarditis associated with seasonal Influenza A virus in Japan.

The questions about the attitudes of Japanese pediatricians to the diagnosis of Influenza myocarditis showed that most of them did not usually assume that their patients had Influenza myocarditis. The ECG was found to be a sensitive and convenient tool for diagnosis of myocarditis in our previous study. ST elevation, T inversion, and conduction block are frequently observed. However, only $3.3 \%$ of Japanese pediatricians ordered routine ECGs on admission for Influenza. Thus, mild cases of myocarditis in children may be missed by pediatricians.

\section{Conclusion}

Increased awareness of Influenza myocarditis in children is very important during future Influenza pandemics.

\section{Acknowledgement}

This study was supported in part by a research grant for intractable diseases from the Ministry of Health, Labor and Walfare, and a grant for scientific research from the Ministry of Education, Science and Culture, Tokyo, Japan. The authors greatly appreciate the excellent assistance of Ms. T. Takabayashi.

\section{References}

1. JCS Joint Working Group (2011) Guidelines for diagnosis and treatment of myocarditis (JCS 2009): digest version. Circ J 75: 734-743.

2. Estabragh ZR, Mamas MA (2013) The cardiovascular manifestations of influenza: a systematic review. Int J Cardiol 167: 2397-2403.

3. Mamas MA, Fraser D, Neyses L (2008) Cardiovascular manifestations associated with influenza virus infection. Int J Cardiol 130: 304-309.
4. Bowles NE, Ni J, Kearney DL, Pauschinger M, Schultheiss HP, et al. (2003) Detection of viruses in myocardial tissues by polymerase chain reaction. evidence of adenovirus as a common cause of myocarditis in children and adults. J Am Coll Cardiol 42: 466-472.

5. Koide H, Kitaura Y, Deguchi H, Ukimura A, Kawamura K, Hirai K (1992) Genomic detection of enteroviruses in the myocardium--studies on animal hearts with coxsackievirus B3 myocarditis and endomyocardial biopsies from patients with myocarditis and dilated cardiomyopathy. Jpn Circ J. 56 :1081-1093.

6. Ukimura A, Izumi T, Matsumori A; Clinical Research Committee on Myocarditis Associated with 2009 Influenza A (H1N1) Pandemic in Japan organized by Japanese Circulation Society (2010) A national survey on myocarditis associated with the 2009 influenza A (H1N1) pandemic in Japan. Circ J 74 2193-2199.

7. Ukimura A, Ooi Y, Kanzaki Y, Inomata T, Izumi T (2013) A national survey on myocarditis associated with influenza H1N1pdm2009 in the pandemic and postpandemic season in Japan. J Infect Chemother 19: 426-431.

8. Ukimura A, Satomi H, Ooi Y, Kanzaki Y. (2012) Myocarditis Associated with Influenza A H1N1pdm2009.Influenza Res Treat. 2012: 351979.

9. Bratincsák A, El-Said HG, Bradley JS, Shayan K, Grossfeld PD, et al. (2010) Fulminant myocarditis associated with pandemic H1N1 influenza A virus in children. J Am CollCardiol 55: 928-929.

10. Weiss TW, Stensaeth KH, Eritsland J (2010) Myocarditis in a juvenile patient with influenza A virus infection. Eur Heart J 31: 277.

11. Aoyama N, Izumi T, Hiramori K, Isobe M, Kawana M, Hiroe M, et al (2002) National survey of fulminant myocarditis in Japan: therapeutic guidelines and long-term prognosis of using percutaneous cardiopulmonary support for fulminant myocarditis (special report from a scientific committee). Circ J. 66: 133-44.

12. Centers for Disease Control and Prevention (CDC) (2010) Patients hospitalized with 2009 pandemic influenza A (H1N1) - New York City, May 2009. MMWR Morb Mortal Wkly Rep 58: 1436-1440.

13. Kerkhove MDV, Vandemaele KA, Shinde V, Jaramillo-Gutierrez G, Koukounar A, et al. (2011) On behalf of the WHO Working Group for Risk Factors for Severe H1N1pdm Infection.: Risk factors for severe outcomes following 2009 influenza A (H1N1) infection: a global pooled analysis. Pros Med. 7: 1-12.

14. The Ministry of Health, Labor, Tokyo, Japan: A National survey of influenza patients in the last winter in Japan (in Japanese). April 1, 2011.

15. Sugaya N (2011) Widespread use of neuraminidase inhibitors in Japan. J Infect Chemother 17: 595-601.

16. Ikematsu $\mathrm{H}$, Kawai $\mathrm{N}$, Kashiwagi $\mathrm{S}$. In vitro neuraminidase inhibitory activities of four neuraminidase inhibitors against influenza viruses isolated in the 2010 2011 season in Japan. J Infect Chemother. 2012; published online Feb.28

17. Pan HY, Yamada H, Chida J, Wang S, Yano M, et al. (2011) Up-regulation of ectopic trypsins in the myocardium by influenza $A$ virus infection triggers acute myocarditis. Cardiovasc Res 89: 595-603.

18. Kotaka M, Kitaura Y, Deguchi H, Kawamura K (1990) Experimental influenza A virus myocarditis in mice. Light and electron microscopic, virologic, and hemodynamic study. Am J Pathol 136: 409-419. 